\title{
無電解はんだめっきの皮膜特性
}

\author{
本間 英夫 ${ }^{*}$ ，高井 英次 ${ }^{* *}$ ，小林 健 ${ }^{* * *}$
}

\section{Properties of Electroless Solder Plated Films}

\author{
Hideo HONMA*, Eiı1 TAKAI** and Takeshı KOBAYASHI***
}

\begin{abstract}
Electroless solder plating by the displacement reaction has been investigated. The addition of free borofluoride and hydroxylamine both improved the stability and extended the life of the plating bath The plating bath reaction was initiated 10s after immersion of the copper substrate into the bath Deposition morphology after 1 min of reaction was similar to the final equilibrium stage of the deposit. Wettability was decreased due to diffusion of copper at film thickness of around $0.5 \mu \mathrm{m}$, but (film thickness of $4 \mu \mathrm{m}$ or more) wettability was excellent with no decrease observed
\end{abstract}

Key Words Electroless Solder Platıng, Displacement Reaction, Solderability

\section{1. 緒言}

近年，プリント配線板や電子部品への無電解スズやは んだめっきの要求が高まっている。しかし無電解による この種のめっきはスズ, 鉛の自己触媒性が無いことから 置換反応を利用した研究が多い(1) 7)。先に著者らは置換 法による無電解はんだめっきについて検討し，スズ及び 鉛のホウフッ化物を基本とした浴にチオ尿素を添加する ことにより，種々の組成のはんだを最高約 $15 \mu \mathrm{m}$ 程度 まで成膜できることを報告した ${ }^{8)}$ 。本報ではさらにホウ フッ化水素酸及び還元剂の添加効果, 初期の成膜挙動, 皮膜特性について検討した結果を報告する。

\section{2. 実験方法}

表 1 に前報の結果に基づいて調製した基本浴組成及び 条件を示す。なお，テストピースとしてハルセル試験用 銅板 $(20 \mathrm{~mm} \times 50 \mathrm{~mm})$ を使用し，前処理として $40^{\circ} \mathrm{C}$ の過硫酸アンモニウム $100 \mathrm{~g} / \mathrm{dm}^{3}$ と濃硫酸 $30 \mathrm{~g} / \mathrm{dm}^{3}$ の 混合液で 30 秒間のエッチングを行った後，室温で水洗 し，めっきを行った。膜厚及び合金比率は蛍光 $\mathrm{X}$ 線微 小部膜厚計（セイコー電子工業(侏製）を用いて測定した。 皮膜の表面形態は走查型電子顕微鏡（日本電子(侏)製）を

* 関東学院大学工学部（干236 神奈川県横浜市金沢区六浦町 4834)

Fac of Eng, Kanto Gakuin Univ. (4834, Mutsuura-cho, Kanazawa-ku, Yokohama-shı, Kanagawa 236)

**関東学院大学工学部（干236 神奈川県横浜市金沢区六浦町 4834）[現. (株)日立製作所]

Fac of Eng, Kanto Gakuin Unıv (4834, Mutsuuracho, Kanazawa-ku, Yokohama-shi, Kanagawa 236) [Present Hitachi Co, Ltd]

****関東学院大学大学院（干236 神奈川県横浜市金沢区六浦町 4834)

Graduate School, Kanto Gakuin Unıv. (4834, Mutsuuracho, Kanazawa-ku, Yokohama-shı, Kanagawa 236)
Table 1 Bath composition and conditions.

\begin{tabular}{ll}
\hline Lead borofluoride & $0.03 \mathrm{~mol} / \mathrm{L}$ \\
Tin borofluoride & $01 \mathrm{~mol} / \mathrm{L}$ \\
Thiourea & $75 \mathrm{~g} / \mathrm{L}$ \\
Temp & $60^{\circ} \mathrm{C}$ \\
& $\mathrm{pH}<1$ \\
Plating time & $60 \mathrm{~min}$ \\
Scale & $100 \mathrm{~mL}$ \\
\hline
\end{tabular}

用いて観察し，はんだ濡れ性はソルダーチェッカー（夕 ムラ化研(㹯)製）を用いてメニスコグラフ法で評価を行っ た。

\section{3. 実験結果及び考察}

\section{1 金属塩濃度の検討}

金属塩濃度の変化に対する膜厚及び析出皮膜中のスズ と鉛の含有率の関係について検討した結果を図 $1 ， 2$ に

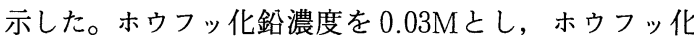
スズ濃度を 0.05〜0.20Mに変化させると，析出速度はス ズイオン濃度の増加とともに増大し，0.10Mの時に最も 高く $7 \mu \mathrm{m} / \mathrm{h}$ となり，それ以上の濃度ではほぼ一定の析 出速度を示した。また，スズ含有率はホウフッ化スズ濃 度の上昇に伴い上昇した。一方，ホウフッ化スズイオン 濃度を $0.10 \mathrm{M}$ し， ホウフッ化鉛濃度を $0.01 \sim 0.04 \mathrm{M}$ に変化させた場合は，ホウフッ化鉛が $0.01 \mathrm{M}$ の時の 9 $\mu \mathrm{m} / \mathrm{h}$ から鉛イオン濃度の増加に伴い析出速度は低下し,

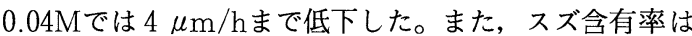
ホウフッ化鉛濃度の上昇に伴い急激に減少した。

\section{2 ホウフッ化水素酸，塩酸ヒドロキシルアミンの} 添加の影響

前報で，鉛とスズのチオ錯体形成の抑制及びスズの酸 化の抑制が無電解はんだめっきを長期間安定に使用する ために重要であり，遊離ホウフッ化水素酸の添加及びヒ 


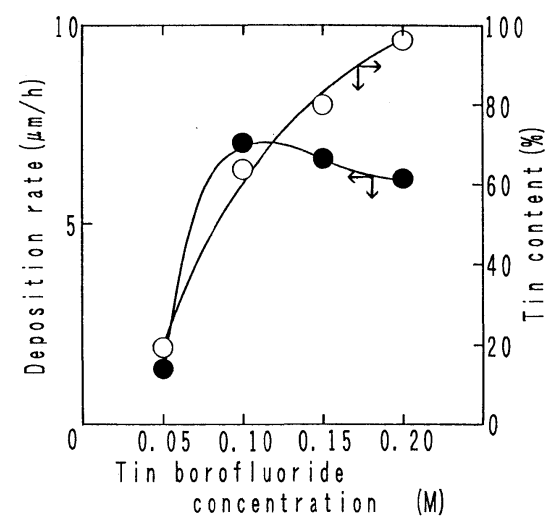

Fig. 1 Effect of tin borofluoride concentration.

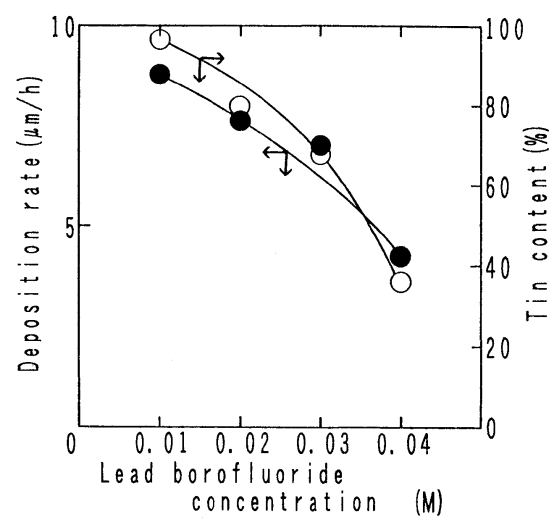

Fig. 2 Effect of lead borofluoride concentration.

ドロキシルアミン, DMABや次亜リン酸などの還元剤 の添加効果が有効であることを確認した。そこで本報で

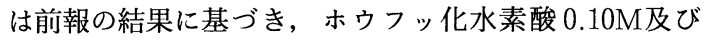
塩酸ヒドロキシルアミン $0.01 \mathrm{M}$ を基本浴に添加し， 60 分間の成膜後, 膜厚, 合金比率へのホゥフッ化水素酸, 塩酸ヒドロキシルアミンの添加の影響について検討した。 この結果を表 2 に示した。これより, 塩酸ヒドロキシル アミン, ホゥフッ化水素酸の添加により析出速度は増大 し，また長期間析出速度が低下することなしに成膜でき ることを確認した。なお, 本報に示した测定結果では析 出速度と組成値に若干の食い違いが認められた。これは, 置換反応によって析出が進行するため, 同一の基板材料 を使用しても常に一定の值を示さないためと考えられる。

\section{3 めっき時間と析出速度, 皮膜中の合金比率}

ホウフッ化水素酸及び塩酸ヒドロキシルアミンを添加 した浴を用いてめっき時間と膜厚, 皮膜中の合金比率に ついての検討を行った結果を図 3 に示した。めっき時間 が 30 分程度までは析出速度は直線的に増加するが，そ の後はゆるやかに析出が進行している。これは銅表面を スズ，鉛が被覆し，ほぼ置換反応が終了したことを示し
Table 2 Effect of additives on deposition rate and tin content.

\begin{tabular}{c|c|c}
\hline & Deposition rate $(\mu \mathrm{m})$ & Tin content (\%) \\
\hline 1 & 3.57 & 56.75 \\
2 & 6.33 & 68.36 \\
3 & 7.01 & 54.81 \\
4 & 9.00 & 66.58 \\
\hline 1 : Basic bath composition \\
2 : Basic bath composition + Hydrofluoroboric acid \\
3 : Basic bath composition + Hydroxylamine hydrochloride \\
4 : Basic bath composition + Hydrofluoroboric acid \\
\multicolumn{2}{|c}{ + Hydroxylamine hydrochloride }
\end{tabular}

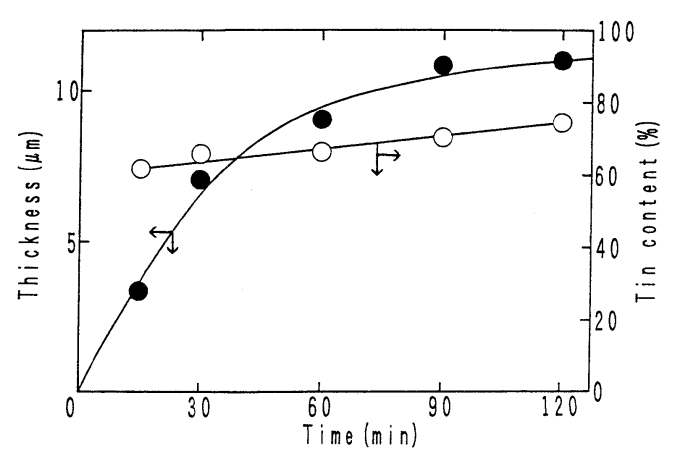

Fig. 3 Effect of plating time on thickness and tin content.

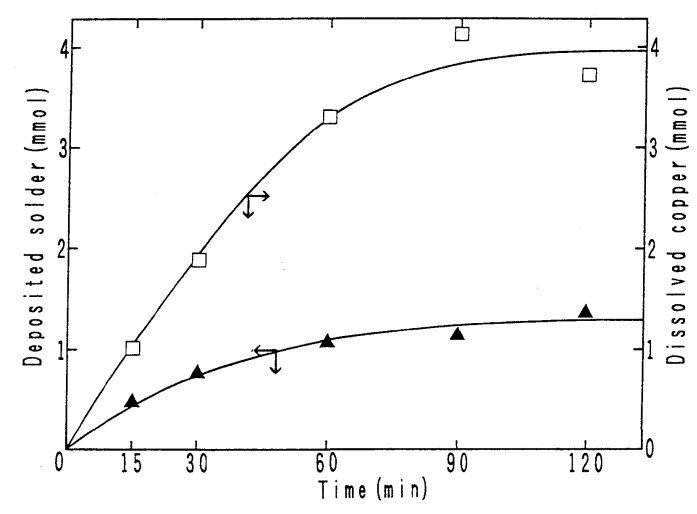

Fig. 4 Relation between deposited solder and dissolved copper.

ている。また，めっき時間の進行とともにスズ含有率は やや増加する傾向を示した。

次に, はんだの析出量と銅の溶出量について調べた結 果を図 4 に示した。その結果, めっき時間 30 分程度ま ではスズ及び鉛の析出量に対して銅の溶出量は 2 倍程度 で置換反応が進行しているが，60分以降では 3 倍程度と なり，銅の溶解反応が優先していることを示している。 また, 実際のはんだの析出量及び銅の溶出量の分析值を 表 3 に示した。 
Table 3 Relation between deposited solder and dissolved copper.

\begin{tabular}{c|c|c|c|c|c}
\hline $\begin{array}{c}\text { Plating } \\
\text { time } \\
(\mathrm{min} .)\end{array}$ & $\begin{array}{c}\text { Solder } \\
\text { thickness } \\
(\mu \mathrm{m})\end{array}$ & $\begin{array}{c}\text { Tin content } \\
(\%)\end{array}$ & $\begin{array}{c}\text { Deposited } \\
\text { solder } \\
(\mathrm{mmol})\end{array}$ & $\begin{array}{c}\text { Dissolved } \\
\text { copper } \\
(\mathrm{mmol})\end{array}$ & $\begin{array}{c}\text { Dissolved } \\
\text { copper } \\
(\mu \mathrm{m})\end{array}$ \\
\hline 15 & 4.22 & 63.97 & 0.49 & 1.07 & 3.7 \\
30 & 6.98 & 66.58 & 0.82 & 1.86 & 6.6 \\
60 & 9.00 & 65.50 & 1.05 & 3.12 & 11.1 \\
90 & 9.49 & 71.27 & 1.14 & 4.11 & 14.6 \\
120 & 11.26 & 74.07 & 1.33 & 3.69 & 13.1 \\
\hline
\end{tabular}

\section{4 浴中への銅イオンの䔄楀の影霓}

そこで，置換反応によって溶出する銅イオンの浴中へ の蓄積による反応性について，銅を添加した模擬老化浴 を建浴し，銅濃度と析出速度及びスズの含有率との関係 について検討した。その結果を図 5 に示した。なお，めっ き浴に添加した銅は，他のアニオン種の影響を避けるた めにホウフッ化銅を使用した。スズの含有率は添加銅濃 度 4000ppmまではほとんど変化はないが, $5000 \mathrm{ppm}$ 前 後で急激に隇少し，6000ppmにおいて約 $20 \%$ となり， その後一定となった。また, 析出速度は $4000 \mathrm{ppm}$ を越 えるあたりから減少し, $8000 \mathrm{ppm}$ で $2 \mu \mathrm{m} / \mathrm{h}$ 程度まで 減少し，その後一定となった。また，添加銅濃度 10000 ppm以上では浴分解した。この結果から，銅濃度 4000 ppm程度までは析出速度及びスズの含有率には影響が ないことを確認した。

\section{5 めっき時間の経過に伴う表面形態の変化}

反応開始直後からの析出形態を観察した結果を図 6 に 示した。析出皮膜は10秒で既に核形成が進行し，1 分 後の析出形態がその後の析出形態と類似しており, 徐々 に厚膜化している様子が確認された。またこの反応は 置換反応で成膜が進行するため，60分及び 90 分の皮膜 で確諗されるように，多孔性の皮膜であった。

\section{6 各種銅系素材へのめっき}

各種銅系素材上へ，めっき時間 5 〜0分間でめっきを 行った結果を図 7 に示した。この結果から，黄銅板を用 いた結果以外はすべて，めっき時間 90 分間で $10 \mu \mathrm{m}$ 以 上の膜厚が得られた。無電解銅めっき皮膜上では 60 分 で $14 \mu \mathrm{m}, 90$ 分で $16 \mu \mathrm{m}$ 以上の膜厚を示し，圧延銅箔 の場合す60分で $12 \mu \mathrm{m}$ 以上であった。これらの結果か ら，いずれの銅系素材上にもかなりの厚付けが可能であ ることを確認した。また，スズの含有率は $60 \%$ 程度で あった。無電解銅めっき皮膜上ではんだの膜厚が厚くな るのは, 他の素材と比較して無電解銅めっきは多結晶体 で皮膜中に多くの欠陥を含んでおり，置換反応に関与す る銅の溶解反応がこれらの中で一番容易に進行するため と考えられる。

\section{7 はんだ濡れ性}

めっき時間を $1 ， 15 ， 30,60$ 分と変化させ，膜厚とは んだ濡れ性の関係をソルダーチェッカーを用いてメニス

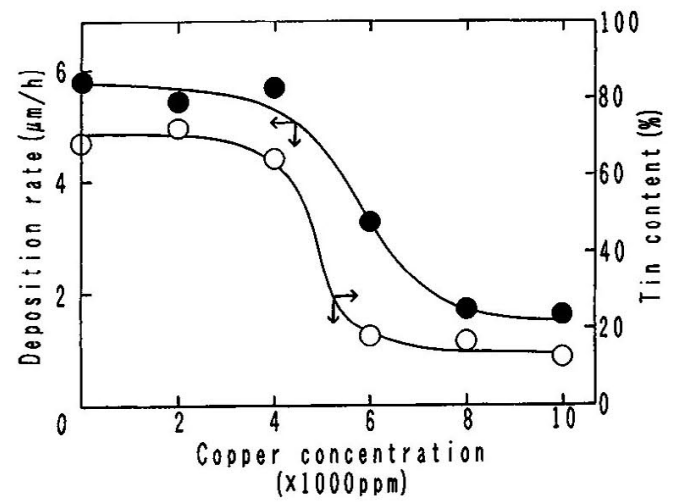

Fig. 5 Effect of copper borofluoride concentration on deposition rate and tin content.

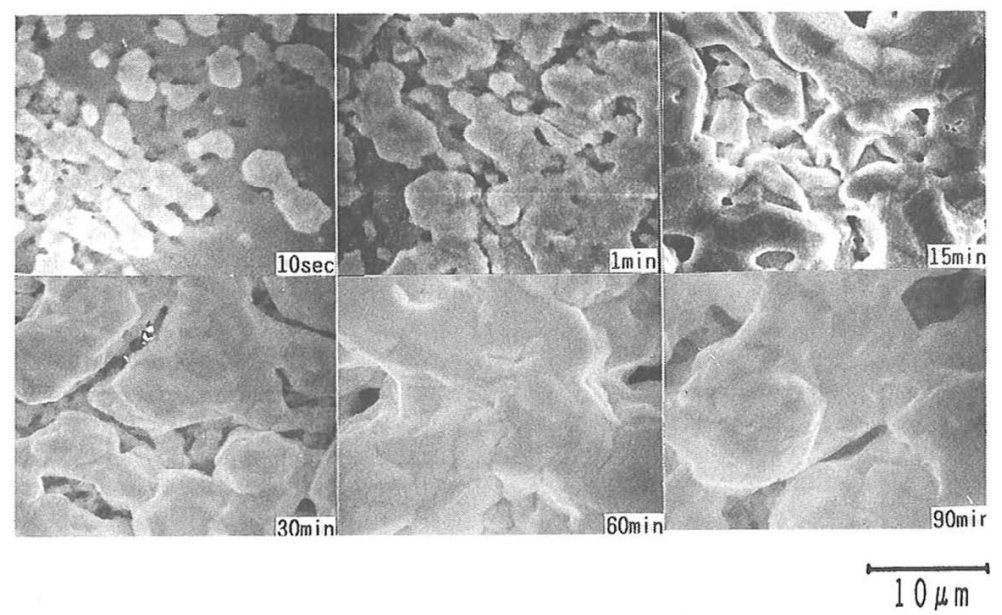

Fig. 6 SEM micrographs of electroless solder deposition. 


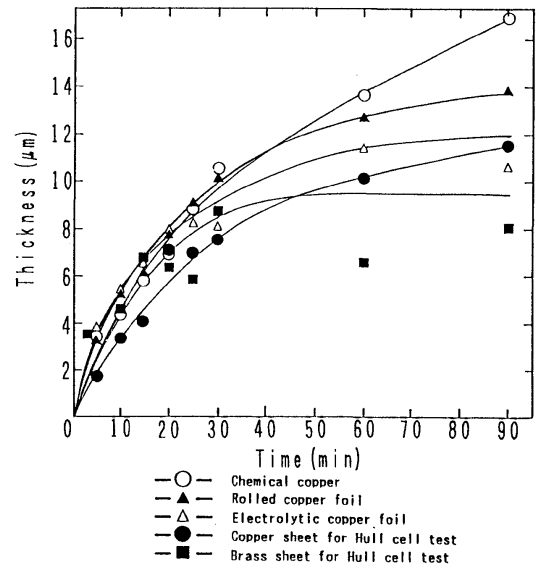

Fig. 7 Effect of different copper substrates on solder thickness.

Table 4 Solder thickness and tin content of samples in solderability test.

\begin{tabular}{c|c|c}
\hline Plating time (min.) & Thickness $(\mu \mathrm{m})$ & Tin content (\%) \\
\hline A (1 min.) & 0.45 & 63.13 \\
B (15min.) & 3.86 & 58.00 \\
C (30min.) & 7.67 & 58.81 \\
D (60min.) & 9.28 & 58.23 \\
\hline
\end{tabular}

Table 5 Measuring conditions of solderability.

\begin{tabular}{ll}
\hline Dipping rate & $24.5 \mathrm{~mm} / \mathrm{s}$ \\
Dipping depth & $3 \mathrm{~mm}$ \\
Dipping time & $10 \mathrm{~s}$ \\
Solder temp. & $245^{\circ} \mathrm{C}$ \\
Flux & L-35 (Tamura Co.) \\
\hline
\end{tabular}

コグラフ法により評価した。評価に用いたサンプルの膜 厚およびスズ含有率を表 4 に示した。また，スズの拡散 の影響を調べるために $170^{\circ} \mathrm{C} て ゙ 4$ 時間加熱した後, 評価 を行った。なお，はんだ濡れ性の測定条件を表 5 に示し た。

図 8 にめっき直後のはんだ需れ性の結果を示したが, 膜厚の差異に影響せず, 濡れ曲線の形状, ゼロクロスタ イムはとあに良好なはんだ濡れ性を示した。また，熱好 理後のはんだ需れ性の結果を図 9 に示した。1 分及び 15分のめっきの場合は, はんだの濡れの速度が低下して いることを確認した。これは, 熱処理によりスズの拡散 が表面層で進行したためと考えられる ${ }^{9}$ 。30分及び 60分 のめっきでは, ゼロクロスタイムは良好な值を示し， ス ズの拡散の影響を受けなかった。なお 60 分のめっきの 試料では濡れ曲線に若干のはじきが認められたが，これ は析出皮膜が多孔性であるためと考えられる。
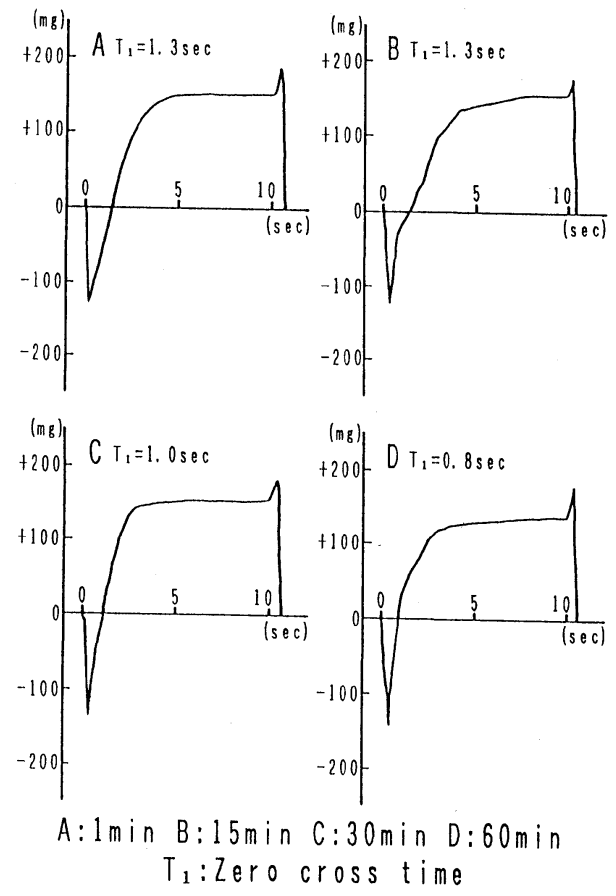

Fig. 8 Solderability of as-plated samples.
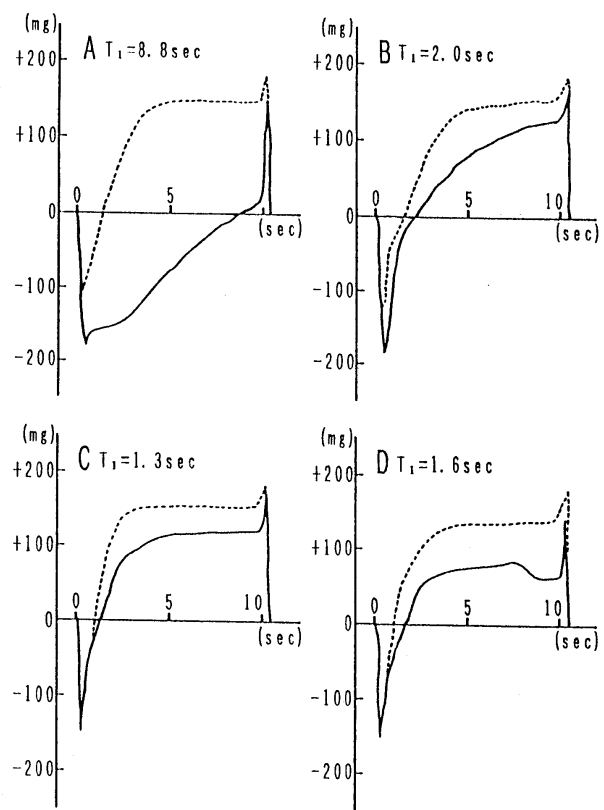

A: $1 \mathrm{~min} B: 15 \mathrm{~min} C: 30 \mathrm{~min} 0: 60 \mathrm{~min}$ $T_{1}:$ Zero cross time

$$
\text { As-plated }
$$

Heat treatment

Fig. 9 Solderability of heat treated samples. 


\section{8 テストパターンでのはんだ需れ性の評価}

次に，はんだ皮膜のリフローによる熱履歴の影響につ いて検討した。すなわち，プリント配線板上に形成した ランド部（直径 $1.0 \mathrm{~cm}$ ）にフラックスを塗布し, リフ ロー後のはんだボール（直径 $0.3 \mathrm{~mm}$ ）の広がりから判 定した。

この評価試料に 60 分間めっきを行ったところ，膜厚 は $136 \mu \mathrm{m}$ ，スズ含有率は $64.5 \%$ あった。個々のラ ンド上にはんだボールを20個所置いて濡れ性を評価し たが，すべて良好に広がった。このように，はんだ広が り法からも良好なはんだ需れ性を確認できた。

\section{4. 結論}

置換析出反応を利用した無電解はんだめっきについて 検討し, 以下の結論を得た。

(1) 金属塩としてスズおよび鉛のホウフッ化物を用いる ことにより, 各種合金比率のはんだめっきを得ることが できた。

(2) はんだの析出量と銅の溶出量から,この無電解はん
だめっきの析出は置換反応で進行していることを確認し た。

(3) 反応は 10 秒後から既に始まり，1 分程度からの析出 形態がその後の析出形態を支配していた。

(4) 析出皮膜は多孔質な皮膜であるが，はんだ濡れ性は 良好であった。

(1992-8-4＼cjkstart受理)

\section{文 献}

1) M E. Warwick and B Shirley, Trans Inst Metal Fintshing, 58, 9 (1980)

2 ）小幡恵吾，園田 司，土肥信康，金属表面技術， $33 ， 375$ (1982)

3 ) 小沢昭弥，高橋武彦，金属表面技術，11，301（1960）

4 ）小谷野英勝，依知川正宏，金属表面技術，38，240（1987）

5 ）小谷野英勝, 依知川正宏, 金属表面技術，39，440（1988）

6) A Molenaar, $J$ Electrochem Soc, 136, 2 (1989)

7) Zakraysek L. ; Plat and Surf Fin, 64, (3), 38 (1977)

8 ) 本間英夫, 河内康徳, 小山田雅明, サーキットテクノロシ, 6, 299 (1991)

9) D M Tench and D P Anderson, Plat and Surf. Fin, 77, (8), 44 (1990) 